\title{
Requirement for the Second Coding Exon of Tat in the Optimal Replication of Macrophage-Tropic HIV-1
}

\author{
Christine Neuveut $^{a}$ Robert M. Scoggins $^{b}$ David Camerini ${ }^{b}$ \\ Richard B. Markham ${ }^{c}$ Kuan-Teh Jeang ${ }^{\text {a }}$ \\ a Laboratory of Molecular Microbiology, National Institute of Allergy and infectious Diseases, Bethesda, Md.; \\ ${ }^{b}$ Myles H. Thaler Center for AIDS and Human Retrovirus Research, University of Virginia Health Science Center, \\ Charlottesville, $\mathrm{Va}_{* ;}$ 'Department of Molecular Microbiology and Immunology, Johns Hopkins School of \\ Public Health, Baltïmore, Md., USA
}

\section{Key Words}

HIV - Macrophage tropism - Tat - AIDS pathogenesis . SCID mouse

\begin{abstract}
HIV-1 Tat is essential for virus replication and is a potent transactivator of viral gene expression. Evidence suggests that Tat also influences virus infectivity and cytopathicity. Here, we find that the second coding exon of Tat contributes a novel function for the replication/infectivity of macrophage-tropic HIV-1. We show that macrophagetropic HIV-1 which expresses the full-length two-exon form of Tat replicates better in monocyte-derived macrophages (MDM) than an otherwise isogenic virus which expresses only the one-exon form of Tat. Similarly, twoexon Tat expressing HIV-1 also replicates better than one-exon Tat expressing HIV-1 in two different models of human cells/tissue reconstituted SCID mice.
\end{abstract}

Copyright $\subseteq 2003$ National Science Council, ROC and S. Karger AG, Basel

\section{Introduction}

Acquired immunodeficiency syndrome (AIDS), the disease induced by HIV-1, is a complex process that involves both multiple viral and host determinants $[8,20$, $26,36]$. AIDS development can be viewed as occurring in three phases: a brief primary infection, followed by a long asymptomatic period, with finally disease manifestation and death. The detailed mechanisms underlying the initiation and development of AIDS remain incompletely understood. However, even at its asymptomatic stage, HIV-1 replicates actively in the host. Hence, even at time of low initial viremia, HIV-1 RNA, nevertheless, can be found in both the circulating peripheral blood as well as in lymphoid organs of infected individuals. Later, very high levels of viral replication with daily production of $10^{7}$ to $10^{9}$ virions accompanied by the demise of about $2 \times 10^{9} \mathrm{CD} 4+\mathrm{T}$ cells/day have been estimated [26].

There is a strong correlation between virus load and disease progression in AIDS [18]. However, the precise sequence of molecular events governing disease development in vivo remains to be fully elucidated. Indeed, the respective roles of macrophage-tropic (M- or CCR5-tropic) and T-cell-tropic (T- or CXCR4-tropic) HIV-1 in

Kuan-Teh Jeang

Laboratory of Molecular Microbiology

National Institute of Allergy and Infectious Diseases

Bethesda, MD 20892-0460 (USA)

Tel. $+13014966680, \mathrm{Fax}+13014803686$, E-Mail kj7e@nih.gov

\section{KARGER
$F a x+41613061234$}

E-Mail karger@karger.ch

www.karger.com
O

S. Karger AG, Basel
$1021-7770 / 03 / 0106-0651 \$ 19.50 / 0$

Accessible online at:

www.katger.com/jbs 
AIDS is still incompletely understood [5]. CCR5-utilizing viruses dominate exclusively in virtually all newly HIV1 -infected individuals. By contrast, more than $50 \%$ of individuals infected with HIV-1 for 7 years or greater will be found to have mostly CXCR4-tropic HIV-1 [5]. One thought is that the transition from a CCR5-using (i.e. macrophage infecting) to a CXCR4-using (i.e. T-cell infecting) HIV-1 reflects the progression to a more rapidly replicating and disease-potent form of virus $[2,23,62]$. Nevertheless, the fact that individuals homozygous for genetic deletion of CCR5, a coreceptor necessary for infection of CD4+ cells by M-tropic HIV-1, are resistant to naturally transmitted HIV-1 infections argues for a critical role of macrophages (and macrophage-tropic HIV-1) in new infections [5].

Tat is essential for HIV-1 replication and viability. Tat is a potent transcriptional activator of the HIV-1 LTR [47] that acts through binding to a nascent TAR leader RNA [6, 7] and functions to enhance the initiation and processive elongation of RNA polymerase II at the viral promoter $[21,30-32,35,49,50,60]$. For its transcriptional function, Tat interacts with a host of cellular factors including Sp1 [17, 63], p300/CBP [4, 40], PKR [12], TBP [34], cyclin T1/ CDK9 [9, 16, 25, 58], Tip60 [33], granulin [27, 57], mRNA capping factors [15], and RNA polymerase II $[22,41]$ amongst others. There is evidence that Tat aids HIV-1 replication through mechanisms in addition to its transcriptional activation of the LTR. Hence, Tat can modulate the expression of cellular genes such as TGF- $\beta$ [37], IL2 [59]; IL6 [3]; Bcl-2 [65], and TNF $\beta$ and $\alpha$. [11]. Moreover Tat is secreted into the extracellular milieu [10, 23, 62] and can activate quiescent $T$ lymphocytes [46].

Tat is encoded by two exons. The first coding exon of Tat spans amino acids 1-72 while the second coding exon spans amino acids 73-101. Findings from subgenomic transfection experiments have demonstrated that the first coding exon of Tat is sufficient for transcriptional activation of the HIV-1 LTR [29, 32], and that deletion of the second coding exon of Tat appears to minimally alter the transactivation of LTR reporter plasmids. However, the second coding exon of Tat is conserved amongst all HIV-1 strains, as well as in HIV-2 and SIV, arguing that this exon likely contains a function important for the virus. Indeed, we have previously shown that the second coding exon of Tat is necessary for optimal virus replication in $\mathrm{T}$ cells [45] and for the chronic in vivo replication of SIV in macaques [56a]. Work from our laboratory has also shown that the second coding exon of Tat interacts with the translation elongation factor $\mathrm{EF}-1 \delta$, an interaction that affects the translation of cellular mRNA in HIV-1 infected cells [61].

Here, we have investigated the contribution of the second coding exon of Tat to replication of HIV-1 in macrophages. We have constructed otherwise isogenic macrophage-tropic HIV-1s which express either the first exon of Tat or the two-exon full-length Tat protein. We have compared the replication of these viruses in MDM and in human cells/tissue-reconstituted SCID (hu-SCID) mice. Our results support that the second coding exon of Tat contributes to optimal virus replication in macrophages. Deletion of the second exon of tat was significantly deleterious for viral replication in vivo in reconstituted hu-PBLSCID mice and hu-SCID (thymus/liver) mice.

\section{Materials and Methods}

\section{Plasmid Constructions}

All molecular viral clones were derived from pNL4-3 [1] engineered by E. Freed to contain an AD8 macrophage-tropic Env (pNLAD8). We have previously described the conditions for infection with pNLAD8-derived macrophage-tropic viruses [51]. Using pNLAD8, we created pNLAD8/lex which expresses only the first coding exon of tat. pNLAD8 was constructed by introducing a stop codon at amino acid 72. pNLAD8/101 was constructed by removing a premature stop codon [32] in pNL4-3 after amino acid 86 of Tat. Here, a single nucleotide change extends the Tat protein in NL4-3 from its 86 amino acids to the 101 amino acid form found in most primary HIV-1 isolates [32]. pNLAD8/m54 and pNLAD8/m60 contain an engineered stop codon at amino acid 54 and 60 , respectively; these two molecular clones encode highly abbreviated forms of Tat.

\section{Cells, Transfection and Viral infections}

U38 cells were culture in RPMI- 1640 with $10 \%$ fetal calf serum. HeLa cells were propagated in Dulbecco's modified Eagle's medium (DMEM with $10 \%$ fetal calf serum). Transfection of HeLa cells was performed using calcium phosphate. Virus production was monitored and normalized by measuring supernatant reverse transcriptase (RT) activity $[45,56]$. U38 cells were electroporated with the various molecular clones using ( $300 \mathrm{~V}$ and $960 \mu \mathrm{F}$; Bio-Rad electroporator). MDM were obtained from elutriated monocytes which were allowed to differentiate over a 14 -day period in $100-\mathrm{mm}^{2}$ bacteriological petri plates and then were transferred to a 24-well tissue culture plates $\left(1 \times 10^{6}\right.$ cells $)$ and allowed to adhere overnight prior to infection [19]. MDM were cultured in DMEM 10\% human serum. Infection of MDM was performed using viruses normalized for RT activity $\left(10^{5} \mathrm{cpm} \mathrm{RT}\right)$. Virus was first absorbed in a small volume $(100 \mu l)$ for $3 \mathrm{~h}$ at $37^{\circ} \mathrm{C}$. TCID50 was determined after infection of human peripheral blood monocytes (PBMC) for 14 days. PBMC were stimulated with phytohemagglutinin (PHA, $250 \mathrm{ng} / \mathrm{ml}$ final concentration) for 3 days prior to infection and were maintained in RPMI-1640 with 20\% fetal bovine calf serum and $10 \%$ interleukin 2 (Pharmacia). Usually $4 \times 10^{3} \mathrm{PBMCs}$ in a $0.1-\mathrm{ml}$ volume were absorbed with virus supernatants. 


\section{Reporter Assays}

CAT assays were performed as previously described [6]. After resolution using $T L C$, the radioactive spots were quantitated using a Fuji phosphorimager. For quantitations, CAT activities were analyzed in the linear range of acetylation. All transfections and corresponding assays were done three to five times.

\section{Reconstitution and Infection of hu-SCID Mice}

For reconstitution of SCID mice with PBL [38], 4- to 6-week-old $\mathrm{CB} 17$ scid/scid mice were injected with $2 \times 10^{7}$ Ficoll-Hypaque (Sigma) purified PBMCs from healthy donors. 8 days later, mice with circulating human IgG concentrations greater than $5 \mu \mathrm{g} / \mathrm{ml}$ were inoculated with the indicated virus. 3 weeks after inoculation, the mice were euthanized and peritoneal cells were obtained by peritoneal lavage with cold PBS. Approximately $5 \times 10^{5}$ peritoneal cells were cocultured with $4 \times 10^{5}$ normal PBMCs that had been stimulated with PHA $(1 \mu \mathrm{g} / \mathrm{ml})$ for $48 \mathrm{~h}$ and maintained in RPMI with IL-2 $(10$ units $/ \mathrm{ml}$ ). Growth of virus from the culture was monitored by virus p24 assay. hu-SCID thymus/liver mice were created by implantation of human fetal thymus and liver fragments under the kidney capsule of C.B-17 SCID/beige mice $[13,52]$ as originally described by Namikawa et al. [44]. C.B-17 SCID/beige mice were obtained from Taconic Farms and bred at the University of Virginia under an agreement with the Fox Chase Cancer Center. SCID/beige and hu-SCID mice were maintained in micro-isolator cages on racks with HEPAfiltered air blown into each cage (Allentown Caging, Allentown, Penn.). The mice were implanted with $1-\mathrm{mm}^{3}$ pieces of human fetal thymus and liver when they were 6-weeks old. Eighteen-week gestational age tissue was obtained from Advanced Bioscience Resources (Alameda, Calif.). One piece of fetal thymus and two of fetal liver were inserted under the left kidney capsule of each mouse using a 16-gauge cancer implant needle set (Popper and Sons, New Hyde Park, N.Y.). The grafts were left undisturbed for 10 months prior to infection with HIV-1. Then, mice were anesthetized with ketamine and xylazine ( 8 and $0.8 \mu \mathrm{g}$, respectively, per gram body weight) injected intraperitoneally prior to infection or biopsy. Methoxyfluorane was used if additional anesthesia was necessary and buprenone was administered to minimize postoperative discomfort for all surgical procedures. Thymus/liver grafts were exteriorized and measured with a caliper. Only grafts larger than or equal to $0.5 \mathrm{~cm}$ in diameter were used. Freshly titered HIV-1 stocks were diluted to $2 \times 10^{4}$ $\mathrm{TCID}_{50}$ per $\mathrm{ml}$ and $1,000 \mathrm{TCID}_{50}$ were injected directly into the thymus/liver grafts in a volume of $50 \mu 1$. hu-SCID mice were biopsied at 3 and 6 weeks after infection. For each biopsy, the grafts were again exteriorized and $1 / 3$ to $1 / 2$ of the tissue, depending on the size of the graft was removed. A single cell suspension was made by mincing the tissue with two scalpels in Iscove's medium (Life Technologies, Rockville, Md.) supplemented with $2 \%$ fetal bovine serum (Omega Scientific, Tarzana, Calif.) and $50 \mu \mathrm{g} / \mathrm{ml}$ gentamicin (Life Technolo-

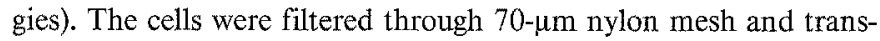
ported on ice from the University of Virginia BL2+ mouse facility to its BL3 laboratory.

\section{Flow Cytometry}

Cells were washed twice in phosphate-buffered saline (PBS), counted and aliquoted at $5 \times 10^{5}$ cells per well into 96 -well V-bottom plates (Costar, Cambridge, Mass.). Fluorochrome-conjugated monoclonal antibodies (mAb) were added to each well and the plates were agitated and incubated $30-60 \mathrm{~min}$ in the dark at $4^{\circ} \mathrm{C} . \mathrm{mAb}$ used were CD7-FITC, CD4-PE (both from CalTag, S. San Francisco, Cal- if.) and CD8-PerCP (BDIS, San Jose, Calif.). Following incubation with $\mathrm{mAb}$, the cells were washed wice with $200 \mu \mathrm{PBS}$, resuspended into $100 \mu \mathrm{PBS}+2 \%$ formaldehyde and incubated for $16 \mathrm{~h}$ at $4^{\circ} \mathrm{C}$ in the dark. Samples were diluted with PBS; and $1 \times 10^{4}$ cells, discriminated by their $90^{\circ}$ and low angle light scattering properties, were analyzed with a FACScan flow cytometer fitted with a helium-neon laser and appropriate filters for the fluorochromes. Data were analyzed using CellQuest software.

\section{Ouantitative PCR}

Genomic DNA was purified using the QIAamp Blood Kit (Qiagen, Valencia, Calif.) from approximately $1 \times 10^{7}$ thymocytes from each biopsy. PCR amplification was performed by an initial denaturation step at $94^{\circ} \mathrm{C}$ for 2 min followed by 23 cycles at $94^{\circ} \mathrm{C}$ for $30 \mathrm{~s}$ and $65^{\circ} \mathrm{C}$ for 1 min with the primer pair M667 and AA55 specific for R/U5 region of HIV-1 LTR [64]. Primers specific for the human $\beta$ globin gene were used to detect cellular DNA. In each case, one of the two primers used was labeled on the free 5 -phosphate using $\mathrm{T} 4$ bacteriophage polynucleotide kinase (NEB, Beverly. Mass.) and $\gamma_{3}{ }^{32} \mathrm{p}-$ ATP. A standard curve for the number of HIV-1 copies was generated for each PCR with 5-fold dilutions of EcoRI-digested $\pi \mathrm{SV}^{\prime} \mathrm{JR}$ CSF mixed with genomic DNA from $1 \times 10^{5}$ peripheral blood mononuclear cells (PBMCs). A standard curve for the number of $\beta$-globin copies was generated for each PCR with 5-fold dilutions of genomic DNA from PBMCs. In both cases the standard curve was only used for the range of values over which a linear regression gave an $R$ value of greater than or equal to 0.98 . Radiolabeled PCR products were resolved by electrophoresis on a $6 \%$ polyacrylamide, $1 \times$ TBE gel. HIV- 1 and $\beta$-globin copy numbers were obtained by interpolation from the standard curve using a Molecular Dynamics Phosphoimager Model 425 (Molecular Dynamics, Sunnyvale, Calif.).

\section{Results}

\section{Construction of Macrophage-Tropic IIIV-I Proviruses \\ Expressing Full-Length or Truncated Tat Protein}

To date, structure /function studies on Tat have focused largely on its first coding exon; little is known regarding the biological role(s) of the second coding exon of Tat. Previously, we had found that the second coding exon of Tat was important for HIV-1 infection of T cells. Because macrophage infection by HIV-1 represents one of the earliest steps in AIDS transmission [28, 42], we were further interested in querying as to how the second coding exon of Tat might also contribute to HIV-1 infection in macrophages.

To address this question, we constructed four otherwise isogenic proviruses containing, respectively, a Tat protein of 72 amino acids (first coding exon of Tat) (pNLAD8/1ex), 101 amino acids (both coding exons of Tat) (pNLAD8/101), 59 amino acids (pNLAD8/m60), or 53 amino acids (pNLAD8/m54). All molecular clones were derived from pNLAD8 which contains the pNL4-3 backbone with an AD8 macrophage-tropic Env. Since pri- 
Fig. 1. Construction of the pNLAD8 proviruses containing full-length two coding exons of Tat, the first coding exon of Tat or further truncated versions of Tat. Schematic representations of pNLAD8, pNLAD8/ 1ex, pNLAD8/101, pNLAD $8 / \mathrm{m} 54$, and pNLAD $8 / \mathrm{m} 60$ are shown. pNLAD8/101 was constructed by releasing a stop codon at position 87 to correct the reading frame to 101 amino acids. pNLAD8/1ex has an introduced stop codon at amino acid 72 . $\mathrm{pNLAD} 8 / \mathrm{m} 60$ and $\mathrm{pNLAD} 8 / \mathrm{m} 54$ were constructed by inserting a stop codon at amino acid 60 and 54 , respectively.

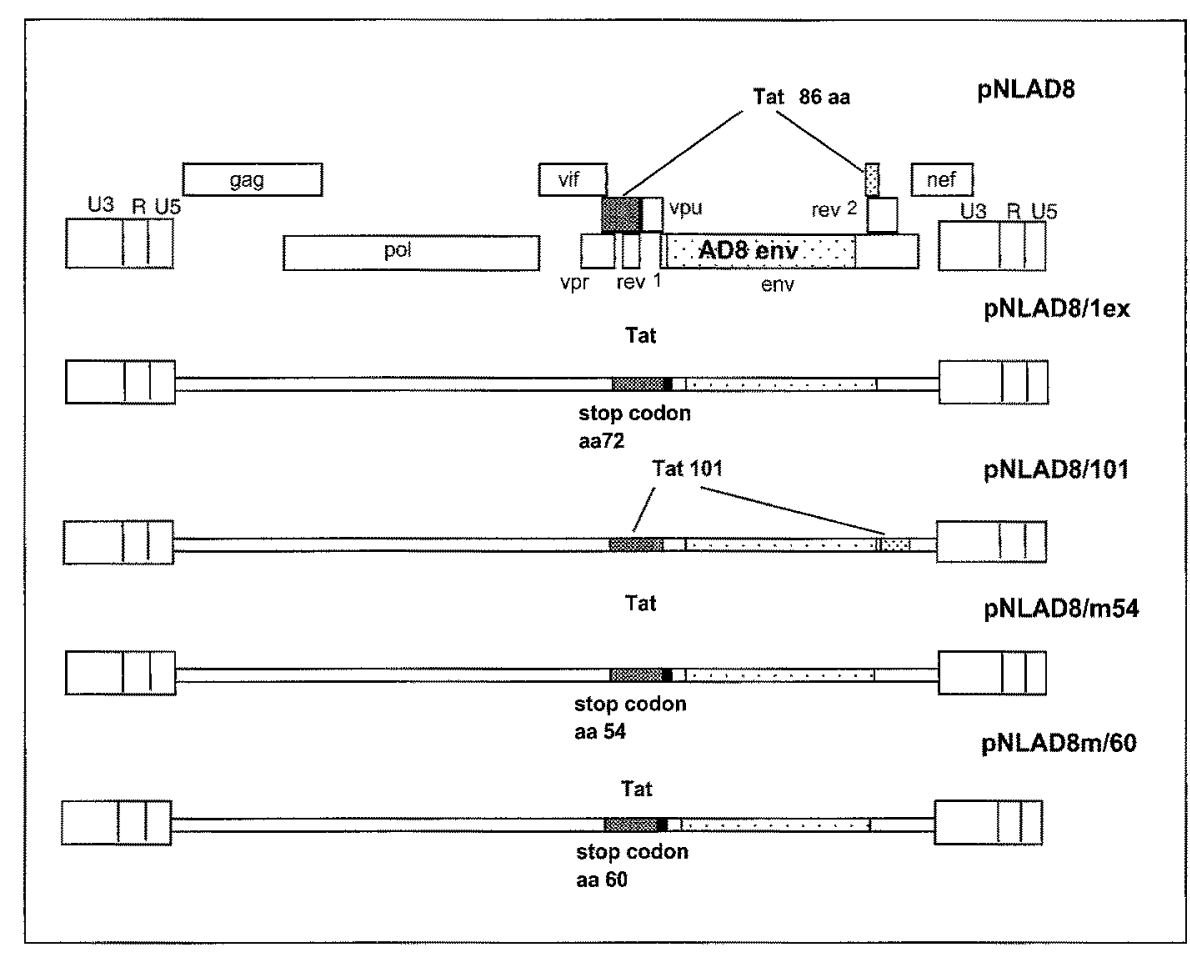

mary isolates of HIV-1 all have a 101 amino acid Tat protein, we re-engineered the prototypic pNL4-3 molecular clone which has a premature stop codon after amino acid 86 to pNLAD8/101 by releasing the stop codon by a single A-to-C nucleotide change. This change did not affect either the rev or env open reading frames. pNLAD8/1ex was constructed by introducing a stop codon at amino acid 72 (a C-to-T change). This mutation also did not disturb the rev open reading frame. The two other mutants, $\mathrm{pNLAD} 8 / \mathrm{m} 60$ and PNLAD $8 / \mathrm{m} 54$, were constructed by introducing a stop codon at amino acid 60 (C-to-T change) and 54 (C-to-T change), respectively. None of these mutations introduced any change into the Rev protein (fig. 1).

\section{Comparable Tat Transcriptional Activity was}

Observed for NLAD8/m60, NLAD8/1ex, NLAD8/101

To check the activity of each modified Tat protein, we separately cotransfected the proviral plasmids into $\mathrm{HeLa}$ cells with an HIV-1-LTR CAT reporter. For these experiments, we titrated escalating amounts of proviral plasmid with a constant amount of reporter. CAT activity was measured $48 \mathrm{~h}$ after transfection. As shown in figure $2 \mathrm{~A}$, three proviruses, pNLAD8/1ex, pNLAD8/101 and PNLAD8/m60, all showed similar activity in the reporter assays (fig. 2A). As expected based on previous mutagene- sis data [32], the provirus containing a stop codon at amino acid 54 of Tat failed to activate the HIV-1 LTR CAT reporter.

The above findings indicated that in reporter assays, the one-exon form of Tat was as potent as its full length two-exon Tat counterpart. To verify that this finding also holds for cells other than HeLa, we next tested the proviruses in a promonocytic cell line, U38. U38 is derived from the promonocytic cell line, U937, and contains a stably transfected HIV-1 LTR CAT reporter. We transfected U38 cells with either pNLAD8/1ex or pNLAD8/101 (fig. 2B, C). Transfected cells were also either mocktreated or treated with phorbol myristic acid (PMA). Similar to the HeLa results, both forms of Tat activated the LTR-CAT reporter comparably. Indeed, unexpectedly, in U38 cells the transcriptional activity of one-exon Tat was slightly better than full-length two-exon Tat.

\section{The Second Coding Exon of tat Contributes to HIV-I \\ Replication in Macrophages}

Although there was no difference between truncated one-exon Tat and full-length two-exon Tat in reporter activation, we considered whether the two forms of Tat might differ in their respective ability to support virus infection in macrophages. To address this, we first used the primary nondividing MDM system previously de- 
Fig. 2. Transcriptional activities of the different Tat proteins. A HIV-1 LTR CAT, at a constant amount, was cotransfected with increasing amounts of the different pNLAD8 molecular clones, as indicated, into HeLa cells. CAT activities were assayed $48 \mathrm{~h}$ after transfection. The activities were expressed in percent acetylation. All the proviruses showed similar transactivation activity except pNLAD $8 / \mathrm{m} 54$ which had near-background activity. B, C The transactivation activities of the Tat-1exon versus Tat 2 -exon protein were analysed in promonocytic cell line U38 treated with $(\mathbf{C})$ or without $(\mathbf{B})$ PMA. Fold induction was calculated relative to the activity measured for HIV LTR-CAT alone.

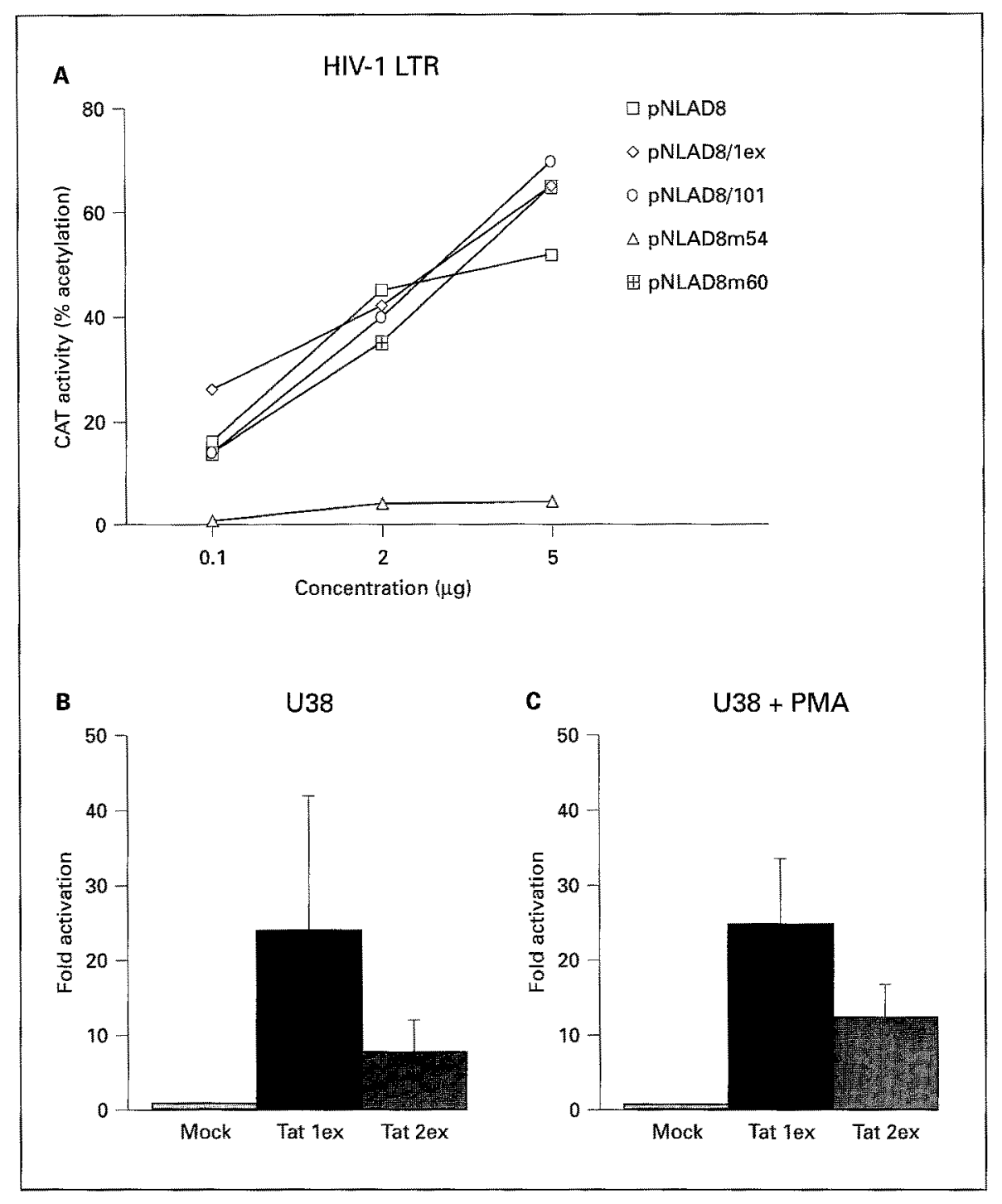

scribed by Englund et al. [19]. MDMs from two different donors (MDM 47 and MDM 58) were maintained in DMEM 10\% human serum without exogenous cytokines. Viruses produced from transfection of HeLa cells and normalized for RT activity were used to infect the two different MDMs.

We followed productive virus infection by monitoring RT secreted into media supernatants from the infected cells. As shown in figure 3, only pNLAD8/m54 failed to replicate in the MDMs. Interestingly, in MDMs, viruses which express either the one-exon Tat protein (pNLAD8/ $1 \mathrm{ex}$ ) or a shorter truncated form (pNLAD8/m60) consistently showed lower RT peaks and a more than 4 daydelay in virus replication when compared to full-length two-exon Tat expressing pNLAD8/101. These infection results strongly suggest that the second exon of tat does contribute to productive HIV-1 replication in macrophages.

\section{The Second Coding Exon of Tat Has a Critical Role in HIV-1 Infection of the Reconstituted hu-SCID}

\section{Mouse}

Data from various laboratories have shown that SCID mice reconstituted with human cells/tissue can be good models for studying M-tropic HIV-1 infection [13, 38, 44, 52]. To verify the biology of pNLAD8/1ex and pNLAD $8 /$ 101 in hu-SCID mice, we assessed their infection profiles using two different SCID models.

In the first model, SCID mice were reconstituted with normal human peripheral blood leukocytes (PBL). Three 


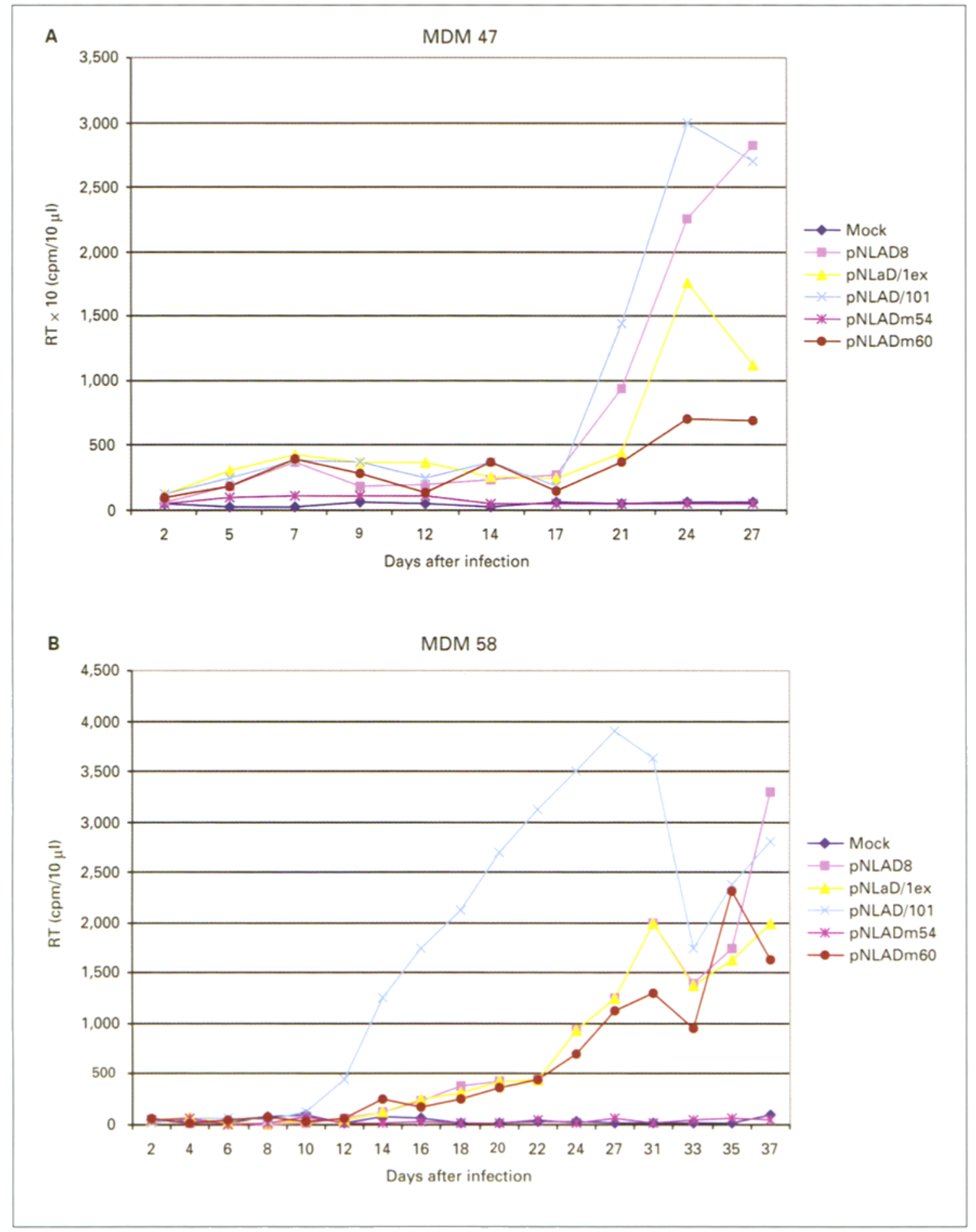

Fig. 3. Preferential replication of pNLAD8/101 in MDM. All pNLAD8-based HIV molecular clones shown in figure 1 were individually transfected into HeLa cells, $48 \mathrm{~h}$ after transfection, virus stocks were normalized for RT and used to infect MDM isolated from two different normal donors referred to as donor 47 (A) and 58 (B).Virus production was monitored by RT assay every 2 or 3 days. 


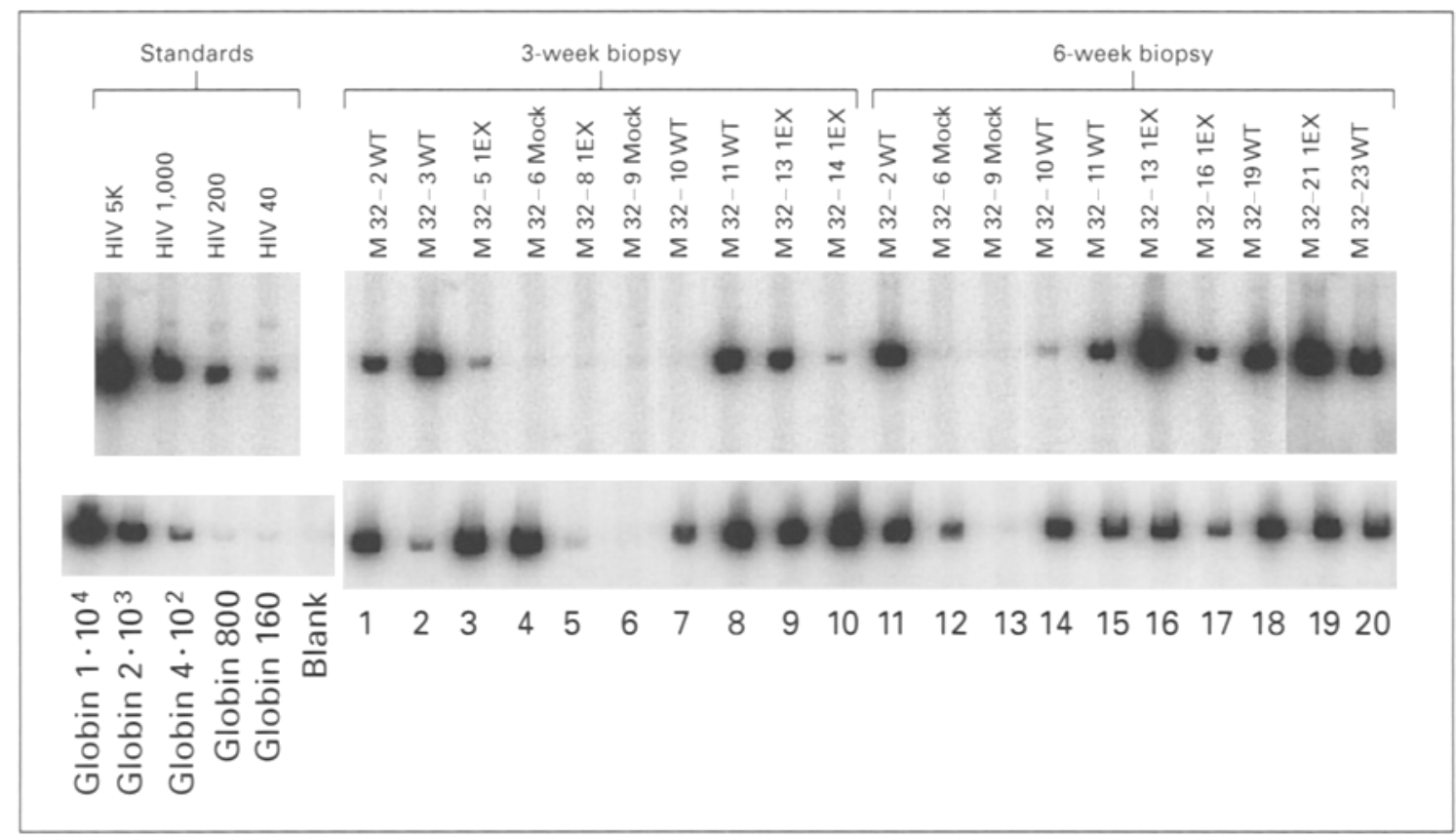

Fig. 4. Quantitative PCR analyses of HIV-1 and $\beta$-globin DNA in human thymus/liver grafts. DNA was isolated from cells derived from human thymus/liver grafts in hu-SCID at the indicated times after infection with HIV-1. Copy number standards for HIV-1 and human $\beta$-globin were prepared as described in Materials and Methods; the number of copies used is listed above and below the bands obtained, respectively. The mouse from which the DNA in each lane was prepared and the virus used to infect the human thymus/liver graft in each mouse is indicated above each lane as follows. Mice are designated M32-2 through M32-23 to indicate that all hu-SCID mice received tissue from the same donor, the 32 nd set of tissue implants done at the University of Virginia, and the mice were numbered sequentially at the time of tissue implantation. The designation WT indicates that the HIV-1 clone, pNLAD8/101, contains a full-length tat gene was used to infect the thymus/liver graft, $1 \mathrm{EX}$ indicates that the HIV-1 clone, pNLAD8/1ex, which only contains the first exon of the tat gene was used. The thymus liver grafts from which DNA was obtained 6 weeks post-infection and run in lanes 17-20 were not biopsied at 3 weeks after infection.
Table 1. Infection of hu-PBL-SCID mice 3 weeks after inoculation with pNLAD8/101, pNLAD8/1ex or pNLAD8/m54

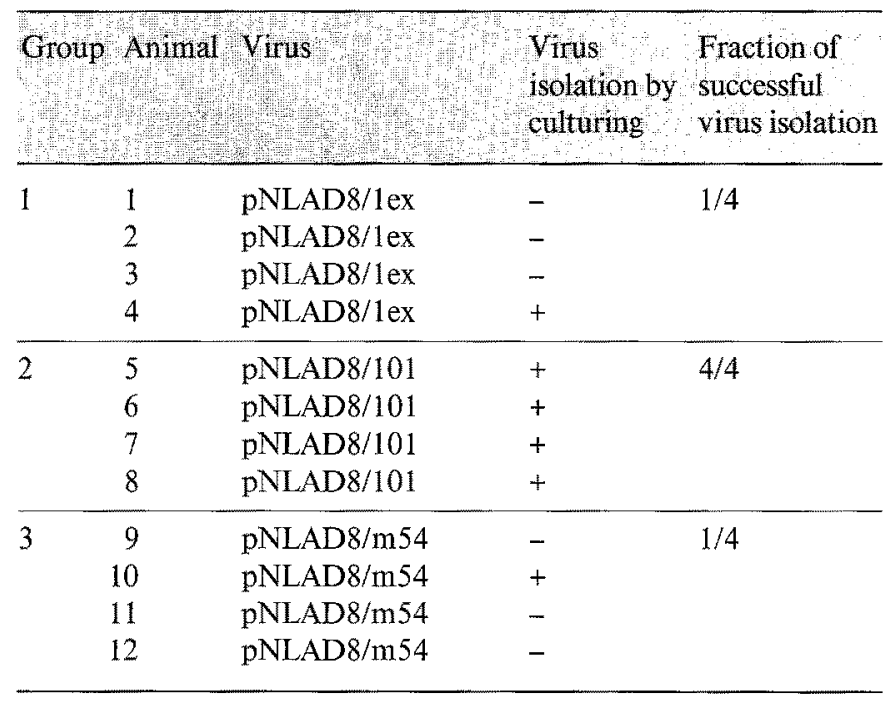

groups of 4 animals per group were tested. Group 1 was infected with pNLAD8/101; group 2 was infected with pNLAD8/1ex; and group 3, used as control, was infected with $\mathrm{pNL} A \mathrm{AD} 8 / \mathrm{m} 54$, a virus which failed to replicate in MDM tissue culture. Three weeks after inoculation, as a readout for productive in vivo infection, we attempted virus isolation using PHA-stimulated human PBMCs and peritoneal washings from the infected mice. We found that 4 out of $4(100 \%)$ pNLAD8/101 inoculated mice produced virus in their peritoneal washings (table 1). On the other hand, both in the pNLAD8/1ex- and the pNLAD8/ m54- group, only 1 out of 4 animals (25\%) yielded culturable virus (table 1). pNLAD8/m54 is both transcriptionaldefective (fig. 2) and macrophage replication defective (fig. 3). The fact that pNLAD8/1ex behaved as pNLAD8/ $\mathrm{m} 54$ in hu-SCID mice while pNLAD8/101 behaved very differently supports that the second exon of Tat (i.e. amino acids 73-101) contributes to in vivo virus replication. 
In a second model, SCID mice were reconstituted with human thymus/liver grafts. In vivo virus propagation was monitored by PCR after isolation of cells from the human grafts 3 and 6 weeks after infection. Here, we also tested 3 separate groups of mice. Mice were inoculated either with pNLAD8/101, or pNLAD8/1ex, or were mock inoculated. Quantitative PCR revealed that NLAD8/101which expresses full-length tat replicated more robustly at 3 weeks after infection than NLAD8/1ex which expresses only the first exon of tat (fig. 4). The average HIV-1 DNA copy number observed 3 weeks after infection by NLAD8/101 was 1,894 per $10^{5}$ cells, while NLAD8/1ex replicated to an average level of 58 copies per $10^{5}$ cells. As expected for this degree of viral replication, no depletion of CD4+ thymocytes was seen by flow cytometry in any of the human thymus liver grafts in this experiment (data not shown). In this mouse model, the replication difference between NLAD8/1 ex compared to NLAD8/101 observed at 3 weeks after infection became less marked at 6 weeks after infection. Collectively, the data from both huSCID models are consistent in supporting the notion that in vivo replication of HIV-1 that expresses full-length Tat is better than counterpart HIV-1 that expresses transcriptionally competent one-exon Tat.

\section{Discussion}

Here we have assessed the contribution of the second coding exon of Tat to the replication of macrophage-tropic HIV-1. We constructed macrophage-tropic molecular clones of HIV-1 which encoded either for the full-length two-exon Tat or a truncated form of first-exon (i.e. 72 amino acids) Tat. We also generated two additional macrophage-tropic HIV-1 viruses that express further abbreviated 53- and 59-amino-acid forms of Tat. Using these four viruses, we asked whether expression of full-length Tat confers a replicative advantage not seen with transcriptionally active but truncated one-exon Tat.

We tested for the contribution of the second coding exon of Tat to HIV-1 replication in macrophages in two independent ways. We checked in vitro infection of MDM and in vivo infection of hu-SCID mice. Both in tissue culture and in animals a consistent finding emerged: replication of pNLAD8/101 is superior to the replication of pNLAD8/1 ex. In tissue culture, depending on the donor, we observed a delay in virus peak of $>4$ days between pNLAD8/1ex and pNLAD8/101 (donor 58; fig. $3 \mathrm{~B}$ ) or a lowered amount of virus production by pNLAD8/1ex (donor 47, fig. 3A). Similarly, the findings from the two reconstituted SCID mouse models (table 1; fig. 4) further confirmed that the second exon of Tat is important for replication of macrophage-tropic HIV-1 in vivo. These results are important since during natural infections macrophages are the first HIV-1 target cells, and the ability to interrupt macrophage-tropic virus replication through targeting Tat $[37,43]$ may offer an early abrogation of disease. A further implication of these results is that should live-attenuated virus be contemplated as a potential HIV-1 vaccine approach $[54,55]$, we would propose that such HIV-1 vectors should express only the first exon of Tat.

Like its counterpart gene, Tax [39], in HTLV-I, the contribution of Tat to HIV-1 replication appears to be multi-faceted. We do not currently know the exact contribution of the second coding exon of Tat to HIV-1 infection of macrophages. This contribution is certain to be independent of Tat's transcriptional activity on the HIV-1 LTR since in transactivation reporter measurements in both HeLa and U38 cells we observed no difference between full-length Tat versus one-exon Tat (fig. 2). Because the transmission/replication/pathogenesis of HIV-1 holds many yet to be understood complexities [14, $24,48,53]$, improved understanding of the in vivo roles of Tat may afford insights that would facilitate the design of early-interruptors of HIV-1 infection. Pending future elucidation of function, engineered small molecules which can specifically target the second exon of Tat could be therapeutically useful.

\section{Acknowledgments}

We thank Ben Berkhout, Anne Gatignol, Stephen Smith, and Monsef Benkirane for useful discussions during various phases of this study. We thank George Englund for expert advice and assistance in MDM production. This work was supported in part by the Intramural AIDS-targeted anti-viral program from the office of the director, NIH. The current address for Dr. Camerini is Department of Molecular Biology and Biochemistry, UC Irvine, Irvine, CA. The current address for Dr. Scoggins is Department of Medicine, Vanderbilt University, Nashville, TN. 


\section{References}

1 Adachi A, Gendelman HE, Koenig S, Folks T, Willey R, Rabson A, Martin MA. Production of acquired immunodeficiency syndrome-associated retrovirus in human and nonhuman cells transfected with an infectious molecular clone. J Virol 59:284-291;1986.

2 Albini A, Ferrini S, Benelli R, Sforzini S, Giunciuglio D, Aluigi MG, Proudfoot $A E$, Alouani S, Wells TN, Mariani G, Rabin RL, Farber JM, Noonan DM. HIV-1 Tat protein mimicry of chemokines. Proc Natl Acad Sci USA 95: 13153-13158;1998.

3 Ambrosino C, Ruocco MR, Chen X, Mallardo M, Baudi F, Trematerra S, Quinto I, Venuta S, Scala G. HIV-1 Tat induces the expression of the interleukin-6 (IL6) gene by binding to the IL6 leader RNA and by interacting with CAAT enhancer-binding protein beta (NF-IL6) transcription factors. J Biol Chem 272:1488314892;1997.

4 Benkirane M, Chun RF, Xian H, Ogryzko VV, Howard BH, Nakatani Y, Jeang KT. Activation of integrated provirus requires histone acetyltransferase. $\mathrm{p} 300$ and P/CAF are coactivators for HIV-1 Tat. I Biol Chem 273:2489824905;1998

5 Berger EA, Murphy PM, Farber JM. Chemokine receptors as HIV-1 coreceptors: roles in viral entry, tropism, and disease. Annu Rev Immunol 17:657-700;1999.

6 Berkhout B, Gatignol A, Rabson AB, Jeang KT. TAR-independent activation of the HIV-1 LTR: evidence that tat requires specific regions of the promoter. Cell 62:757-67;1990.

7 Berkhout B, Silverman RH, Jeang KT. Tat trans-activates the human immunodeficiency virus through a nascent RNA target. Cell 59: 273-82;1989.

8 Blankson JN, Persaud D, Siliciano RF. The challenge of viral reservoirs in HIV-1 infection. Annu Rev Med 53:557-93;2002.

9 Bres V, Tagami H, Peloponese JM, Loret E, Jeang KT, Nakatani Y, Emiliani S, Benkirane M, Kiernan RE. Differential acetylation of Tat coordinates its interaction with the co-activators cyclin T1 and PCAF. EMBO J 21:68116909;2000.

10 Brigati C, Giacca M, Noonan DM, Albini A. HIV Tat, its TARgets and the control of viral gene expression. FEMS Microbiol Lett 220:57$65 ; 2003$

11 Buonaguro L, Buonaguro FM, Giraldo G, Ensoli $B$. The human immunodeficiency virus type 1 Tat protein transactivates tumor necrosis factor beta gene expression tbrough a TARlike structure. J Virol 68:2677-82:1994.

12 Cai R, Carpick B, Chun RF, Jeang KT, Williams BR. HIV-I TAT inhibits PKR activity by both RNA-dependent and RNA-independent mechanisms. Arch Biochem Biophys 373:361367:2000.

13 Camerin D, Su HP, Gamez-Torre G, Johnson ML, Zack JA, Chen IS. Human immunodeficiency virus type 1 pathogenesis in SCID-hu mice correlates with syncytium-inducing phenotype and viral replication. J Virol 74:3196$3204: 2000$.

The Second Exon of Tat Is Required for the Replication of HIV-1
14 Chen YM, Rey WY, Lan YC, Lai SF, Huang YC, Wu SI, Liu TT, Hsiao KJ. Antibody reactivity to HIV-1 Vpu in HIV-1/AIDS patients on highly active antiretroviral therapy. J Biomed Sei 10:266-275;2003.

15 Chiu YL, Coronel E, Ho CK, Shuman S, Rana TM. HIV-1 Tat protein interacts with mammalian capping enzyme and stimulates capping of TAR RNA. J Biol Chem 276:12959-129566; 2001.

16 Chun RF, Jeang KT. Requirements for RNA polymerase II carboxyl-terminal domain for activated transcription of human retroviruses human T-cell lymphotropic virus I and HIV-1. J Biol Chem 271:27888-27894;1996.

17 Chun RF, Semmes OJ, Neuveut C, Jeang KT. Modulation of $\mathrm{Sp} 1$ phosphorylation by human immunodeficiency virus type 1 Tat. J Virol 72 : 2615-2629;1998

18 Coffin JM. HIV viral dynamics. AIDS 10(suppl 3):S75-S84;1996.

19 Englund G, Theodore TS, Freed EO, Engleman A, Martin MA. Integration is required for productive infection of monocyte-derived macrophages by human immunodeficiency vinus type 1. J Virol 69:3216-3219;1995.

20 Gallo RC. Human retroviruses after 20 years: a perspective from the past and prospects for their future control. Immunol Rev 185:236$265 ; 2000$.

21 Garber ME, Jones KA. HIV-1 Tat: coping with negative elongation factors. Curr Opin Immunol 11:460-465;1999.

22 Garcia-Martinez LF, Ivanov D, Gaynor RB Association of Tat with purified HIV-1 and HIV-2 transcription preinitiation complexes. J Biol Chem 272:6951-6958;1997.

23 Ghezzi S, Noonan DM, Aluigi MG, Vallanti G, Cota M, Benelli R, Morini M, Reeves JD, Vicenzi E, Poli G, Albini A. Inhibition of CXCR4-dependent HIV-1 infection by extracellular HIV-1 Tat. Biochem Biophys Res Commun 270:992-996;2000.

24 Hahn T, Ramakrishnan R, Ahmad N. Evalua tion of genetic diversity of human immunodeficiency virus type $1 \mathrm{NEF}$ gene associated with vertical transmission. J Biomed Sci 10:436$450 ; 2003$.

25 Herrmann CH, Rice AP. Lentivirus Tat proteins specifically associate with a cellular protein kinase, TAK, that hyperphosphorylates the carboxyl-terminal domain of the large subunit of RNA polymerase II: candidate for a Tat cofactor. J Virol 69:1612-1620;1995.

26 Ho DD. Perspectives series: host/pathogen interactions. Dynamics of HIV-1 replication in vivo. J Clin Invest 99:2565-2567:1997.

27 Hoque M, Young TM, Lee CG, Serrero G, Mathews MB, Pe'ery T. The growth factor granulin interacts with cyclin $\mathrm{T} 1$ and modulates $\mathrm{P}-\mathrm{TEFb}$-dependent transcription. Mol Cell Biol 23:1688-1702;2003
28 Igarashi T, Brown CR, Endo Y, Buckler-White A, Plishka R, Bischofberger N, Hirsch V, Martin MA. Macrophage are the principal reservoir and sustain high virus loads in rhesus macaques after the depletion of CD4 $+\mathrm{T}$ cells by a highly pathogenic simian immunodeficiency virus/HIV type 1 chimera (SHIV): Implications for HIV-1 infections of humans. Proc Natl Acad Sci USA 98:658-663;2001.

29 Jeang KT, Berkhout B, Dropulic B. Effects of integration and replication on transcription of the HIV- 1 long terminal repeat. J Biol Chem 268:24940-24949:1993.

30 Jeang KT, Berkhout B. Kinetics of HIV-1 long terminal repeat trans-activation. Use of intragenic ribozyme to assess rate-limiting steps. $\mathrm{J}$ Biol Chem 267:17891-17899;1992.

31 Jeang KT, Shank PR, Kumar A. Transcriptional activation of homologous viral long terminal repeats by the human immunodeficiency virus type 1 or the human T-cell leukemia virus type I tat proteins occurs in the absence of de novo protein synthesis. Proc Natl Acad Sci USA 85:8291-8295; 1988 .

32 Jeang KT, Xiao H, Rich EA. Multifaceted activities of the HIV-1 transactivator of transcription, Tat. J Biol Chem 274:28837-28840 1999.

33 Kamine J, Elangovan B, Subramanian T, Coleman D, Chinnadurai $G$. Identification of a cellular protein that specifically interacts with the essential cysteine region of the HIV-1 Tat transactivator. Virology 216:357-366;1996.

34 Kashanchi F, Piras G, Radonovich MF, Duvall JF, Fattaey A, Chiang CM, Roeder RG, Brady JN. Direct interaction of human TFIID with the HIV-1 transactivator tat. Nature 367:295299;1994.

35 Kiernan RE, Vanhulle C, Schiltz L, Adam E, Xiao H, Maudoux $\mathrm{F}$, Calomme C, Burny A, Nakatani Y, Jeang KT, Benkirane M, Van Lint C. HIV-1 tat transcriptional activity is regulated by acetylation. EMBO J 18:6106 -6118; 1999.

36 Kinter A, Arthos J, Cicala C, Fauci AS. Chemokines, cytokines and HIV: a complex network of interactions that influence HIV pathogenesis. Immunol Rev 177:88-98;2000.

37 Lohr M, Kibler KV, Zachary I, Jeang KT, Selwood DL. Small HIV-1-Tat peptides inhibit HIV replication in cultured T-cells. Biochem Biophys Res Commun 300:609-613;2003.

38 Markham RB, Schwartz DH, Templeton A, Margolick $J B$, Farzadegan $\mathrm{H}$, Vlahov $\mathrm{D}, \mathrm{Yu}$ $X F$. Selective transmission of human immunodeficiency virus type 1 variants to SCID mice reconstituted with human peripheral blood monoclonal cells. J Virol 70:6947-6954; 1996.

39 Marriott SJ, Lemoine FJ, Jeang KT. Damaged DNA and miscounted chromosomes: human T cell leukemia virus type I tax oncoprotein and genetic lesions in transformed cells. J Biomed Sci 9:292-298;2002. 
40 Marzio G, Tyagi M, Gutierrez MI, Giacca M. HIV-1 tat transactivator recruits $\mathrm{p} 300$ and CREB-binding protein histone acetyltransferases to the viral promoter. Proc Natl Acad Sci USA 95:13519-24;1998.

41 Mavankal G, Ignatius Ou SH, Oliver H, Sigman D, Gaynor RB. Human immunodeficiency virus type 1 and 2 Tat proteins specifically interact with RNA polymerase II. Proc Natl Acad Sci USA 93:2089-2094;1996.

42 Meltzer MS, Skillman DR, Gomatos PJ, Kalter DC, Gendelman HE. Role of mononuclear phagocytes in the pathogenesis of human immunodeficiency virus infection. Annu Rev Immunol 8:169-194;1990.

43 Mischiati C, Jeang KT, Feriotto G, Breda L, Borgatti M, Bianchi N, Gambari R. Aromatic polyamidines inhibiting the Tat-induced HIV-1 transcription recognize structured TARRNA. Antisense Nucleic Acid Drug Dev 11: 209-217;2001.

44 Namikawa R, Kaneshima H, Lieberman M, Weissman IL, McCune JM. Infection of the SCID-hu mouse by HIV-1. Science 242:1684 $1686 ; 1988$.

45 Neuveut C, Jeang KT. Recombinant human immunodeficiency virus type 1 genomes with tat unconstrained by overlapping reading frames reveal residues in Tat important for replication in tissue culture. J Virol 70:5572$5581 ; 1996$.

46 Ott M, Emiliani S, Van Lint C, Herbein G, Lovett J, Chirmule N, McCloskey T, Pahwa S, Verdin E. Immune hyperactivation of HIV-1infected $T$ cells mediated by Tat and the CD 28 pathway. Science 275:1481-1485;1997.

47 Pereira LA, Churchill MJ, Elefanty AG, Gouskos T, Lambert PF, Ramsay RG, Deacon NJ. Characterization of interactions between transcription factors and a regulatory region spanning $n t-320$ to -281 of the HIV-1 LTR in Tlymphoid and non-T-lymphoid cells. J Biomed Sei 9:68-81;2002.

48 Persaud D, Zhou Y, Siliciano JM, Siliciano RF. Latency in human immunodeficiency virus type 1 infection: no easy answers. J Virol $77: 1659-1665 ; 2003$.
49 Ping $Y H$, Rana TM. Tat-associated kinase (PTEFb): a component of transcription preinitiation and elongation complexes. J Biol Chem 274:7399-7404:1999.

50 Rana TM, Jeang KT. Biochemical and functional interactions between HIV-1 Tat protein and TAR RNA. Arch Biochem Biophys 365: 175-185;1999.

51 Rich EA, Orenstein JM, Jeang KT. A macrophage-tropic HIV-t that expresses green fluorescent protein and infects alveolar and blood monocyte-derived macrophages. J Biomed Sci 9:721-726;2002.

52 Scoggins RM, Taylor JR Jr, Patrie J, van't Wout $\mathrm{AB}$, Schuitemaker $\mathrm{H}$, Camerini $\mathrm{D}$. Pathogenesis of primary $\mathrm{R} 5$ human immunodeficiency virus type 1 clones in SCID-hu mice. J Virol 74:3205-16;2000.

53 Shehu-Xhilaga M, Lee JY, Campbell S, Marshall JA, Crowe SM, Mak J. Overexpression and incorporation of Gag Pol precursor does not impede packaging of HIV-1 tRNA(Lys3) but promotes intracellular budding of viruslike particles. J Biomed Sci 9:697-705;2002.

54 Smith SM. HIV vaccine development in the nonhuman primate model of AIDS. $\mathbf{J}$ Biomed Sci 9:100-111:2002.

55 Smith SM, Khoroshev M, Marx PA, Orenstein $\mathrm{J}_{\text {, Jeang }} \mathrm{KT}$. Constitutively dead, conditionally live HIV-1 genomes, Ex vivo implications for a live virus vaccine. $\mathrm{I}$ Biol Chem 276:32184$32190 ; 2001$

56 Smith SM, Markham RB, Jeang KT. Conditional reduction of human immunodeficiency virus type 1 replication by a gain-of-herpes simplex virus 1 thymidine kinase function. Proc Natl Acad Sci USA 93:7955-7660;1996.

56a Smith SM, Pentlicky S, Klase Z, Singh M, Neuvent $C$, Lu CY, Reitz MS Jr, Yarchoan $R$, Marx $P A$, Jeang KT. An in vivo replication-important function in the second coding exon of Tat is constrained against mutation despite CTL selection. J Biol Chem 2003 (in press).
57 Trinh DP, Brown KM, Jeang KT. Epithelin/ granulin growth factors: extracellular cofactors for HIV-1 and HIV-2 Tat proteins. Biochem Biophys Res Commun 256:299-306;1999.

58 Wei P, Garber ME, Fang SM, Fischer WH, Jones KA. A novel CDK9-associated C-type cyclin interacts directly with HIV-1 Tat and mediates its high-affinity, loop-specific binding to TAR RNA. Cell 92:451-462;1998.

59 Westendorp MO, Li-Weber M, Frank RW, Krammer PH. Human immunodeficiency virus type 1 Tat upregulates interleukin-2 secretion in activated T cells. J Virol 68:4177-4185; 1994.

$60 \mathrm{Xiao}$ H, Lis JT, Jeang KT. Promoter activity of Tat at steps subsequent to TATA-binding protein recruitment. Mol Cell Biol 17:6898-6905; 1997.

61 Xiao H, Neuveut C, Benkirane M, Jeang KT. Interaction of the second coding exon of Tat with human EF-1 delta delineates a mechanism for HIV-1-mediated shut-off of host mRNA translation. Biochem Biophys Res Commun 244:384-389;1998.

62 Xiao H, Neuveut C, Tiffany HL, Benkirane M, Rich EA, Murphy PM, Jeang KT. Selective CXCR4 antagonism by Tat: implications for in vivo expansion of coreceptor use by HIV-1. Proc Natl Acad Sci USA 97:11466-11471; 2000.

63 Yedavalli VS, Benkirane M, Jeang KT. Tat and trans-activation-responsive (TAR) RNA-independent induction of HIV-1 long terminal repeat by human and murine cyclin $\mathrm{T} 1$ requires Sp1. J Biol Chem 278:6404-6410;2003.

64 .Zack JA, Arrigo SJ, Weitsman SR, Go AS, Haislip A, Chen IS. HIV-1 entry into quiescent primary lymphocytes: molecular analysis reveals a labile, latent viral structure. Cell 61 : 213-222;1990

65 Zhang M, Li X, Pang X, Ding L, Wood O, Clouse KA, Hewlett I, Dayton AI. Bcl-2 upregulation by HIV-1 Tat during infection of primary human macrophages in culture. J Biomed Sci 9:133-139;2002. 